\title{
Model Pelatihan Kecakapan Hidup dan Pendampingan Kewirausahaan terhadap Upaya Memelihara Kemampuan Keaksaraan
}

\author{
Asep Supriyatna \\ Institut Pendidikan Indonesia \\ Garut-Jawa Barat \\ Email : asupriyatna59@gmail.com
}

\begin{abstract}
The illiteracy returned by some of the leaners who have taken basic level literacy education is proved. This happen because it is not maintained and / or not used in everyday life. On the other hand adult literacy is an important component of the education aspect which can increase the human development index.This study was designed using Research and Development method with data analysis techniques conducted by comparing the conditions before and after using the model of life skills training and entrepreneurship accompanied (before-after) to one group (one group pretest-posttest design ) with one type of treatment. The results of the study show that the new model has proved effective in an effort to maintain the literacy skills of leaner at basic level functional literacy education.
\end{abstract}

Keywords: Life skills training, entrepreneurship accompanied, and literacy.

\begin{abstract}
Abstrak
Buta aksara kembali dari sebagian warga belajar yang sudah mengikuti pendidikan keaksaraan fungsional tingkat dasar terbukti adanya. Hal ini terjadi dikarenakan tidak terpelihara dan/atau tidak digunakan dalam kehidupan sehari-hari. Di sisi lain tingkat keaksaraan orang dewasa merupakan komponen penting dari aspek pendidikan yang dapat menaikkan indeks pembangunan manusia.

Penelitianinididesaindenganmenggunakanpendekatan PenelitiandanPengembangan, atau Research and Development dengan tehnik analisis data yang dilakukan dengan cara membandingkan keadaan sebelum dan sesudah menggunakan model pelatihan kecakapan hidup dan pendampingan kewirausahaan (before-after) terhadap satu kelompok (one group pretest-posttest design)dengan satu macam perlakuan.

Hasilpenelitianmenunjukanbahwamodel baru terbukti efektif dalam upaya memelihara kemampuan keaksaraan warga belajar pendidikan keaksaraan fungsional tingkat dasar.
\end{abstract}

Kata kunci : Pelatihan kecakapan hidup, pendampingan kewirausahaan, dan keaksaraan.

\section{PENDAHULUAN}

Keaksaraan adalah kemampuan membaca, menulis, dan berhitung serta memiliki kemampuan fungsional yang diperlukan dalam kehidupan sehari-hari. Untuk kepentingan itu beragam program pendidikan keaksaraan telah dilakukan termasuk salah satunya adalah pendidikan keaksaraan fungsional tingkat dasar yang telah diikuti oleh masyarakat sebagai warga belajar Pusat Kegiatan Belajar Masyarakat (PKBM) Riung Gunung di Kecamatan Bungbulang Kabupaten Garut Provinsi Jawa Barat. Namun, fenomena munculnya buta aksara kembali dari sebagian warga belajar yang sudah dibelajarkan terbukti adanya. Sebagian besar warga belajar keaksaraan fungsional dari 15 peserta, 10 peserta mengalami buta aksara kembali karena tidak 
terpelihara dan/atau tidak digunakan dalam kehidupan sehari-hari. Fenomena ini juga sesuai dengan tulisan Suryadi (2009: 102) yang menyebutkan bahwa :”...buta aksara kembali setelah mengikuti program pendidikan keaksaraan diperkirakan mencapai $30 \%$.

Pada awalnya ide mengenai keaksaraan fungsional bertujuan membuat peserta didik buta aksara mampu berfungsi sesuai dengan budayanya sendiri, tetapi sejak konferensi UNESCO di Teheran-Iran tahun 1965, menurut Bhola (Kusmiadi, 2009: 11), menyatakan :'...telah terjadi peralihan pemikiran dan keaksaraan fungsional jadi lebih terkait dengan ekonomi yang berarti bahwa tujuan akhir dari keaksaraan adalah untuk membantu pihak penerima (sasaran didik) mampu berfungsi dalam kehidupan ekonomi'. Melalui pendekatan ekonomi diharapkan dapat lebih memotivasi warga belajar dalam memelihara keaksaraan selaras dengan pendapat Kusnadi, dkk (2005: 10) yang menyebutkan : “...beralasan bahwa motivasi ekonomi memainkan peranan utama dalam kaitannya dengan keaksaraan fungsional". Nampaknya cukup beralasan bahwa pendekatan ekonomi dapat memainkan peranan dalam upaya memelihara keaksaraan masyarakat, mengingat buta aksara dan kemiskinan merupakan dua dimensi yang tidak dapat dipisahkan, sesuai dengan tulisan Suryadi (2009:101) yang menyebutkan :

Buta aksara dan kemiskinan merupakan dua dimensi yang tidak terpisahkan. Permasalahan mendasar dalam pembangunan masyarakat miskin yang terjadi selama ini adalah tidak dimilikinya kemampuan keaksaraan dari sebagian besar penduduk miskin, yang mengakibatkan mereka tidak mampu mengakses informasi untuk dapat berpartisipasi dalam pembangunan. Untuk itu sangatlah perlu dilakukan program dan strategi yang inovatif, efisien dan efektif untuk memberantas buta aksara dan kemiskinan secara bersamaan.

Berdasarkan hal di atas, menunjukkan bahwa upaya memelihara keaksaraan masyarakat atau warga belajar perlu dicarikan model yang lebih efektif dari model yang sudah ada sebagaimana pendapat Sihombing (1999: 52) bahwa “...pendidikan masyarakat itu tidak perlu harus ada program yang standar, berbagai model harus dikembangkan". Salah satu model yang akan dikonstruk oleh peneliti adalah model pelatihan kecakapan hidup dan pendampingan kewirausahaan, dengan demikian nama modelnya adalah : "Model Pelatihan Kecakapan Hidup dan Pendampingan Kewirausahaan terhadap Upaya Memelihara Kemampuan Keaksaraan Warga Belajar di Kecamatan Bungbulang Kabupaten Garut Provinsi Jawa Barat". Melalui model yang dikonstruk peneliti tersebut di atas, diharapkan dapat menjawab permasalahan dan atau tujuan penelitian karena sesungguhnya konsep pelatihan kecakapan hidup tidah hanya peningkatan kemampuan vokasional semata, tetapi peningkatan pula kemampuan pesonal, kemampuan sosial dan kemampuan akademik. Demikian juga pendampingan kewirausahaan adalah upaya pendampingan pasca pelatihan/pendidikan keaksaraan yang dilakukan oleh Tutor terhadap warga belajar dalam hal menjaga kelangsungan kegiatan ekonomi disertai dengan penguatan kewirausahaan seperti percaya diri, berorientasi pada tugas dan hasil, menyukai tantangan dan berani mengambil risiko, berperilaku sebagai pemimpin, kreatif dan inovatif, serta berorientasi ke masa depan yang nampak dalam kemampuan berwirausaha atau menjalankan kegiatan ekonomi keseharian (kegiatan produksi yang meliputi kegiatan pengadaan bahan baku dan proses produksi, kegiatan distribusi berupa pemasaran serta keuangan berupa perhitungan laba/rugi perusahaan secara sederhana), sehingga pada akhirnya dapat memelihara kemampuan keaksaraan warga belajar disamping diharapkan dapat mengembangkan ilmu pendidikan khususnya Pendidikan Luar Sekolah dan Bahasa Indonesia. 
Sebagaimana telah dijelaskan, bahwa penelitian ini berangkat dari permasalahan sebagian besar warga belajar yang pernah mengikuti pembelajaran atau pendidikan keaksaraan fungsional tingkat dasar tidak lagi melakukan kegiatan keaksaraan seperti membaca, menulis, berhitung dan berbicara dalam bahasa Indonesia sebagaimana kebiasaan yang sebelumnya mereka lakukan. Akhirnya kemampuan keaksaraan mereka tidak terpelihara. Itu lah salah satu fenomena buta aksara kembali yang terjadi pada warga belajar khususnya di Kecamatan Bungbulang Kabupaten Garut. Peneliti menduga bahwa sebagian besar warga belajar tidak ada kegiatan yang dapat memaksa dan membiasakan untuk memelihara kemampuan keaksaraan mereka seperti antara lain melalui kegiatan ekonomi atau wirausaha sesuai dengan minat dan bakatnya serta adanya pemahaman dan penerapan yang kurang dalam memaknai pelatihan kecakapan hidup dari penyelenggaran pendidikan keaksaraan yang selama ini dimaknai hanya sebatas kecakapan vokasional, padahal pelatihan kecakapan hidup meliputi empat kecakapahan yaitu : kecakapan personal, kecakapan sosial, kecakapan akademik, dan kecakapan vokasional (Hatimah, dkk., 2007: 84). Penyebab selanjutnya adalah tidak diikuti oleh proses pendampingan pasca pelatihan. Suharto (2007: 95) menulis bahwa pendampingan adalah suatu proses lanjut pemberdayaan masyarakat melalui penerapan fungsi pemungkinan, 'enabling' atau fasilitasi, penguatan, 'empowering', perlindungan, 'protecting', dan pendukungan, 'supporting'. Pelatihan kecakapan hidup dan pendampingan merupakan model konseptual yang dapat diterapkan sebagai suatu proses belajar dan berlatih yang terintegrasi yang terdiri dari kecakapan personal, kecakapan sosial, kecakapan akademik, dan kecakapan vokasional ditindak lanjuti oleh penerapan fungsi pemungkinan atau fasilitasi, penguatan, perlindungan, dan pendukungan untuk menjadikan kegiatan ekonomi atau wirausaha sebagai media pemeliharaan kemampuan keaksaraan mereka. Dari permasalahan, penyebab serta landasan teori yang relevan, maka rumusan masalah penelitiannya adalah :

Dapatkah model pelatihan kecakapan hidup dan pendampingan kewirausahaan secara signifikan memelihara kemampuan keaksaraan warga belajar?

Untuk memudahkan proses pemecahan masalah, permasalahan tersebut dapat dirinci menjadi tiga pertanyaan, yaitu :

1. Bagaimanakah deskripsi empirik kemampuan keaksaraan warga belajart pasca mengikuti pendidikan keaksaraan fungsional ?

2. Bagaimanakah deskripsi empirik kemampuan keaksaraan warga belajar setelah tidak melakukan kegiatan ekonomi ?

3. Dapatkah model pelatihan kecakapan hidup dan pendampingan kewirausahaan secara signifikan memelihara kemampuan keaksaraan warga belajar?

Tujuan penelitian ini adalah untuk menemukan model pelatihan kecakapan hidup dan pendampingan kewirausahaan yang efektif untuk memelihara keaksaraan warga belajar pendidikan keaksaraan yang sebelumnya pernah mengikuti pembelajaran keaksaraan fungsional tingkat dasar.

Selanjutnya tujuan dan keutamaan penelitian tersebut dapat dirinci sebagai mana disebutkan di bawah ini.

1. Memperoleh gambaran tentang kemampuan keaksaraan warga belajar pendidikan keaksaraan pasca mengikuti pendidikan keaksaraan fungsional.

2. Memperoleh gambaran tentang kemampuan keaksaraan warga belajar pendidikan keaksaraan setelah tidak melakukan kegiatan ekonomi. 
3. Memperoleh informasi tentang efektivitas model pelatihan kecakapan hidup dan pendampingan kewirausahaan terhadap upaya pemeliharaan keaksaraan warga belajar pendidikan keaksaraan.

\section{KAJIAN PUSTAKA}

Penelitian ini dilakukan dengan menggunakan dasar pijakan teori yang telah dikembangkan oleh para ahli dalam bidang yang relevan dengan topik penelitian ini yang meliputi konsep tentang: pelatihan kecakapan hidup, pendampingan kewirausahaan, dan keaksaraan.

\subsection{Konsep Pelatihan Kecakapan Hidup}

Adapun pengertian pelatihan antara lain didefinisikan oleh Wahyudin (2000: 5.6) :"... adalah suatu proses belajar dan berlatih yang bertujuan untuk meningkatkan keterampilan peserta dalam waktu relatif singkat". (2) Kecakapan hidup didefinisikan oleh Broling (Hatimah, 2007: 8.4) yang menyatakan bahwa: "Kecakapan hidup adalah interaksi berbagai pengetahuan dan kecakapan yang sangat penting dimiliki oleh seseorang sehingga mereka dapat hidup mandiri". Selanjutnya Hatimah (2007: 8.4) memberi penjelasan bahwa: "... Makna kecakapan hidup lebih luas dari sekedar keterampilan untuk bekerja. Kecakapan hidup terdiri dari kecakapan personal, kecakapan sosial, kecakapan akademik, dan kecakapan vokasional".

Yang dimaksud dengan pelatihan kecakapan hidup dalam penelitian ini adalah, upaya peningkatan kecakapan warga belajar keaksaraan fungsional yang meliputi kecakapan personal, sosial, akademik dan vokasional dalam kegiatan ekonomi atau wirausaha wajit dan opak, pemasaran serta pencatatan dan pelaporan keuangan secara sederhana dan teratur teratur.

Adapun pengertian dari beberapa variabel kunci yang diharapkan dapat mengatasi permasalahan penelitian, adalah : (1) Pelatihan didefinisikan oleh Wahyudin (2000 : 5.6) :"...adalah suatu proses belajar dan berlatih yang bertujuan untuk meningkatkan keterampilan peserta dalam waktu relatif singkat". (2) Kecakapan hidup didefinisikan oleh Broling (Hatimah, 2007: 8.4) yang menyatakan bahwa: "Kecakapan hidup adalah interaksi berbagai pengetahuan dan kecakapan yang sangat penting dimiliki oleh seseorang sehingga mereka dapat hidup mandiri". Selanjutnya Hatimah (2007: 8.4) memberi penjelasan bahwa: "... Makna kecakapan hidup lebih luas dari sekedar keterampilan untuk bekerja. Kecakapan hidup terdiri dari kecakapan personal, kecakapan sosial, kecakapan akademik, dan kecakapan vokasional" serta (3) Pendampingan dikutip dari tulisan Suharto (2007: 95) yang menyatakan bahwa: "Pendampingan adalah suatu proses lanjut pemberdayaan masyarakat melalui penerapan fungsi pemungkinan, 'enabling' atau fasilitasi, penguatan, 'empowering', perlindungan, 'protecting', dan pendukungan, 'supporting".

\subsection{Konsep Pendampingan Kewirausahaa 9}

Berikut ini dituliskan tentang kon ndampingan, kewirausahaan serta pendampingan kewirausahaan secara singkat sebagaimana di bawah ini.

\subsubsection{Konsep Pendampingan}

Suharto (2007: 95) menulis bahwa pendampingan adalah suatu proses lanjut pemberdayaan masyarakat melalui penerapan fungsi pemungkinan 'enabling' atau fasilitasi, penguatan, 'empowering', perlindungan, 'protecting', dan pendukungan, 'supporting". Pelatihan kecakapan hidup dan pendampingan merupakan model konseptual yang dapat diterapkan sebagai suatu proses belajar dan berlatih yang terintegrasi yang terdiri dari kecakapan personal, kecakapan sosial, kecakapan akademik, dan kecakapan vokasional ditindak lanjuti oleh penerapan fungsi 
pemungkinan atau fasilitasi, penguatan, perlindungan, dan pendukungan untuk mempercepat proses pertumbuhan wirausaha.

\subsubsection{Konsep Kewirausahaan}

Meskipun sampai sekarang ini belum ada terminologi yang persis sama tentang kewirausahaan, 'entrepreneurship', akan tetapi pada umumnya memiliki hakikat yang hampir sama yaitu merujuk pada sifat, watak dan ciri-ciri yang melekat pada seseorang yang mempunyai kemauan keras untuk mewujudkan gagasan inovatif ke dalam dunia usaha yang nyata dan dapat mengembangkannya dengan tangguh. Menurut Drucker (Suryana, 2003: 13) disebutkan bahwa: "Kewirausahaan adalah suatu kemampuan untuk menciptakan sesuatu yang baru dan berbeda, 'ability to create the new and different thing"'.

Menurut Zimmerer (Suryana, 2003: 10) menulis bahwa kewirausahaan adalah: "Applying creativity and innovation to solve the problems and to exploit opportunities that people face everyday". Kewirausahaan adalah penerapan kreativitas dan inovasi untuk memecahkan masalah dan upaya untuk memanfaatkan peluang yang dihadapi setiap hari. Kewirausahaan merupakan gabungan dari kreativitas, inovasi, dan keberanian menghadapi risiko yang dilakukan dengan cara kerja keras untuk membentuk dan memelihara usaha baru. Menurut Harvard's Theodore Levitt yang dikutip Zimmerer (Usman, 1997: 5) kreativitas adalah berpikir sesuatu yang baru, 'thinking new things', sedangkan inovasi adalah melakukan sesuatu yang baru, 'doing new things'. Keberhasilan wirausaha akan tercapai apabila berpikir dan melakukan sesuatu yang baru atau sesuatu yang lama yang dilakukan dengan cara yang baru 'thinking and doing new things or old thing in new ways'.

Dari pandangan para ahli di atas Soemahamidjaja (1980: 23) menyimpulkan bahwa kewirausahaan pada hakekatnya adalah suatu kemampuan dalam berpikir kreatif dan berperilaku inovatif yang dijadikan dasar, sumber daya, tenaga penggerak, tujuan, siasat, dan kiat dalam menghadapi tantangan hidup.

Dari beberapa konsep yang dikemukakan di atas, ada enam hakikat penting kewirausahaan, Suryana (2003 : 13) menyimpulkannya sebagai berikut: (1) Kewirausahaan adalah suatu nilai yang diwujudkan dalam perilaku yang dijadikan dasar sumber daya, tenaga penggerak, tujuan, siasat, kiat, proses, dan hasil bisnis, (2) Kewirausahaan adalah suatu kemampuan untuk menciptakan sesuatu yang baru dan berbeda, 'ability to create the new and different', (3) Kewirausahaan adalah suatu proses penerapan kreativitas dan inovasi dalam memecahkan persoalan dan menemukan peluang untuk memperbaiki kehidupan (usaha), (4) Kewirausahaan adalah suatu nilai yang diperlukan untuk memulai suatu usaha, 'start-up phase' dan perkembangan usaha, 'venture growth', (5) Kewirausahaan adalah suatu proses dalam mengerjakan sesuatu yang baru, 'creative', dan sesuatu yang berbeda (innovatif) yang bermanfaat memberikan nilai lebih, (6) Kewirausahaan adalah usaha menciptakan nilai tambah dengan jalan mengkombinasikan sumber-sumber melalui cara-cara baru dan berbeda untuk memenangkan persaingan. Nilai tambah tersebut dapat diciptakan dengan cara mengembangkan teknologi baru, menemukan pengetahuan baru, menemukan cara baru untuk menghasilkan barang dan jasa baru yang lebih efisien, memperbaiki produk dan jasa yang sudah ada, dan menemukan cara baru untuk memberikan kepuasan kepada konsumen.

Berdasarkan ke enam konsep diatas, secara ringkas kewirausahaan dapat didefinisikan sebagai suatu kemampuan kreatif dan inovatif, 'create new and different' 
yang dijadikan kiat, dasar, sumber daya, proses, dan perjuangan untuk menciptakan nilai tambah barang dan jasa yang dilakukan dengan keberanian untuk menghadapi risiko.

Banyak ahli yang mengemukakan karakteristik kewirausahaan dengan konsep yang berbeda-beda. Meredith (1996: 6) misalnya mengemukakan ciri-ciri dan watak kewirausahaan seperti berikut:

\begin{tabular}{|l|l|}
\hline \multicolumn{1}{|c|}{ CIRI-CIRI } & \multicolumn{1}{|c|}{ WATAK } \\
\hline Percaya diri & $\begin{array}{l}\text { Keyakinan, ketidaktergantungan, individualitas, dan } \\
\text { optimisme }\end{array}$ \\
\hline Berorientasi pada tugas dan hasil & $\begin{array}{l}\text { Kebutuhan untuk berprestasi, berorientasi laba, } \\
\text { ketekunan dan ketabahan, tekad kerja keras, } \\
\text { mempunyai dorongan kuat, energik dan inisiatif }\end{array}$ \\
\hline $\begin{array}{l}\text { Pengambilan risiko dan suka } \\
\text { tantangan }\end{array}$ & Kemampuan untuk mengambil risiko yang wajar \\
\hline Kepemimpinan & $\begin{array}{l}\text { Perilaku sebagai pemimpin, bergaul dengan orang } \\
\text { lain, menanggapi saran-saran dan kritik }\end{array}$ \\
\hline Keorsinilan & Inovatif dan kreatif serta fleksible \\
\hline Berorientasi ke masa depan & Berpandangan ke depan, perspektif \\
\hline
\end{tabular}

Gambar 1. Ciri dan Watak Kewirausahaan.

\subsubsection{Konsep Pendampingan Kewirausahaan}

Yang dimaksud dengan pendampingan kewirausahaan dalam penelitian ini adalah, upaya pendampingan pasca pelatihan/pendidikan keaksaraan yang dilakukan oleh Tutor terhadap warga belajar dalam hal menjaga kelangsungan kegiatan ekonomi disertai dengan penguatan motivasi berwirausaha seperti percaya diri, berorientasi pada tugas dan hasil, menyukai tantangan dan berani mengambil risiko, berperilaku sebagai pemimpin, kreatif dan inovatif, serta berorientasi ke masa depan yang nampak dalam kemampuan berwirausaha atau menjalankan kegiatan ekonomi keseharian (kegiatan produksi yang meliputi kegiatan pengadaan bahan baku dan proses produksi, kegiatan distribusi berupa pemasaran serta keuangan berupa perhitungan laba/ rugi perusahaan secara sederhana).

\subsection{Konsep Keaksaraan Definisi keaksaraan}

Terdapat beberapa definisi keaksaraan yang dapat ditemukan dalam berbagai referensi, dan berikut ini adalah beberapa pakar yang mengemukakan definisi keaksaraan tersebut.

Kusnadi, et al (2005: 76) memberikan batasan-batasan dari beberapa istilah yang sering digunakan dalam program pendidikan keaksaraan sebagai berikut: (1) Seseorang dikatakan buta aksara, bila orang tersebut tidak memiliki kemampuan "menulis dan membaca" sebuah kalimat pendek sederhana dalam kehidupan seharihari; (2) Seorang yang melek aksara adalah orang memiliki kemampuan "menulis dan membaca" sebuah kalimat pendek sederhana dalam kehidupan sehari-hari; (3) Seorang yang buta aksara fungsional adalah orang yang tidak mampu terlibat dalam semua kegiatan yang memerlukan kemampuan melek huruf, dan juga tidak mempunyai akses untuk melanjutkan penggunaan kemampuan baca-tulis-hitung untuk pengembangan diri dan lingkungan masyarakatnya; (4) Sebaliknya seorang yang melek huruf fungsional adalah yang terlibat dalam semua kegiatan yang memerlukan kemampuan melek huruf, dan juga mempunyai akses untuk melanjutkan penggunaan kemampuan baca-tulis-hitung untuk pengembangan diri dan lingkungan masyarakatnya; (5) 
Tingkat melek aksara adalah prosentase penduduk yang melek aksara, sedangkan tingkat buta aksara adalah presentase penduduk yang buta aksara dalarn suatu negara. Atau bisa juga dihitung dengan cara mengurangi tingkat melek aksara dari proporsi $100 \%$. Tingkatan seperti ini biasanya dihitung bagi penduduk usia 15 tahun ke atas. Berkaitan dengan usia tersebut, di Indonesia biasanya dihitung dari umur 10-44 tahun. Karena pada rentang usia tersebut mereka masih tergolong usia produktif.

Selanjutnya Kusnadi, et al (2005: 77) memberikan definisi keaksaraan: ”... Sebagai kemampuan untuk membaca dan menulis". Akan tetapi, definisi keaksaraan untuk di Indonesia masih menurut Kusnadi (2005: 79): ”... Lebih menitik beratkan kepada peningkatan kualitas hidup dan pemberdayaan masyarakat".

Definisi lain ditulis oleh Abdulhak (1990: 22) yang memberi definisi keaksaraan (literacy) ke dalam beberapa makna, yaitu:

Pertama, literasi adalah kemampuan membaca, menulis dan berhitung yang dituntut bagi seseorang dalam kehidupan bermasyarakat; Kedua, literasi adalah kemampuan membaca, menulis dan berhitung yang digunakan sabagai alat belajar, atau alat khusus untuk memahami dan merubah kehidupan diri beserta lingkungannya.

Demikian juga Uyu Wahyudin (2008: 43-47) memberi pengertian khusus tentang keaksaraan yaitu kemampuan membaca, menulis dan berhitung sebagai berikut: (1) Kemampuan membaca, adalah kemampuan memahami isi bacaan yang dibutuhkan warga belajar dalam kebutuhan sehari-hari, (2) Kemampuan menulis, adalah kemampuan menulis yang diperoleh warga belajar setelah mengikuti kegiatan belajar sesuai dengan tujuan yang telah ditetapkan. Ciri-ciri warga belajar yang telah memiliki kemampuan menulis ditandai oleh: Tulisan yang dihasilkan rapih dan dapat dibaca, banyaknya tulisan yang dihasilkan dalam sejumlah waktu yang telah ditetapkan sesuai dengan kriteria, dan memiliki kesamaan bentuk tulisan dengan lambang huruf atau tanda baca lain yang telah ditetapkan, dan (3) Kemampuan berhitung, adalah kemampuan mengoperasionalkan bilangan untuk memecahkan masalah-masalah yang timbul pada kehidupan sehari-hari.

Dari beberapa definisi yang dikemukakan oleh para ahli tersebut di atas, dapat disimpulkan bahwa keaksaraan adalah kemampuan membaca, menulis, dan berhitung serta memiliki kemampuan fungsional yang diperlukan dalam kehidupan sehari-hari.

Selanjutnya yang dimaksud dengan keaksaraan dalam penelitian ini adalah kemampuan keaksaraan dasar seperti nampak pada indikator : (1) mampu membar dan menulis kalimat sederhana (terdiri atas subyek, predikat, dan obyek) sekuran kurangnya 7 kata dengan menggunakan bahasa Indonesia; (2) mampu melakuk perhitungan penjumlahan, pengurangan, perkalian, dan pembagian angka $1-100$; daı (3) mampu berkomunikasi dengan menggunakan bahasa Indonesia secara lisan.

\section{METODE PENELITIAN}

\subsection{Metode Penelitian yang Digunakan}

Penelitian ini didesain dengan menggunakan pendekatan "Penelitian dan Pengembangan, 'Research and Development"'. Menurut Borg and Gall (1996:782), model penelitian dan pengembangan adalah "A process used develop and validate educational product". Proses ini berlangsung secara siklus, mulai dari tahap pengkajian topik yang ingin dikonstruksi, pengembangan model konseptual, pengujicobaan di lapangan, sampai pada perbaikan model dengan mengoreksi kekurangankekurangan yang ditemukan. Sedangkan menurut Sugiyono (2007: 333), metode 
penelitian dan pengembangan adalah metode penelitian yang digunakan untuk menghasilkan produk tertentu, dan menguji keefektifan produk tersebut.

\subsection{Responden dan Lokasi Penelitian}

Responden dalam penelitian ini adalah warga belajar pendidikan keaksaraan fungsional tingkat dasar yang bermasalah yang pernah mengikuti pendidikan keaksaraan sebelumnya yaitu 10 orang ( purposive sampling ) yang berdomisili di Kecamatan Bungbulang Kabupaten Garut Provinsi Jawa Barat.

\subsection{Teknik dan Alat Pengumpulan Data}

Teknik pengumpulan data yang digunakan dalam penelitian ini berupa pengamatan nonpartisipan terstruktur, wawancara terstruktur tertutup, studi dokumentasi berupa mempelajari laporan penyelenggaraan pelatihan model lama, serta melakukan proses evaluasi berupa tes perbuatan terhadap model konseptual baru.

\subsection{Teknik Analisis Data}

Tehnik analisis data yang dilakukan adalah dengan cara membandingkan keadaan sebelum dan sesudah (before-after) menggunakan model pelatihan kecakapan hidup dan pendampingan kewirausahaan terhadap satu kelompok (one group pretest-posttest design) dengan satu macam perlakuan.

\subsection{Analisis Hasil}

Untuk analisis hasil digunakan beberapa tahapan analisis sebagai berikut :

a. Membuat hipotesis

Hipotesis untuk kasus t-Test adalah:

$\mathrm{H}_{0}: \mu_{1}=\mu_{2}$ atau $\mu_{1}-\mu_{2}=0$, artinya tidak ada perbedaan antara rata-rata data sebelum dengan setelah pengembangan model pelatihan kecakapan hidup dan pendampingan kewirausahaan, atau pengembangan model pelatihan kecakapan hidup dan pendampingan kewirausahaan kurang efektif.

$\mathrm{H}_{1}: \mu_{1}<\mu_{2}$ atau $\mu_{1}-\mu_{2}<0$

Arinya, ada perbedaan antara rata-rata data sebelum dengan setelah pengembangan model pelatihan kecakapan hidup dan pendampingan kewirausahaan atau pengembangan model pelatihan kecakapan hidup dan pendampingan kewirausahaan dinilai efektif.

b.Menentukan t-tabel dan t-hitung

Untuk t-tabel, tingkat signifikansi adalah 5\% ( $\alpha=0.05)$, sedangkan degree of freedom $(d f)$ sebesar $\mathrm{n}-1=9$ Untuk program Excel nilai probabilitas harus dikali 2 , sehingga untuk 0,05 dalam program menjadi $\mathrm{t}_{(0.1,10)}$ pada $\mathrm{t}$ tabel satu sisi (one tail). Untuk menentukan t-tabel dan t-hitung, digunakan "Anal' Statistik Excel" atau menggunakan SPSS Versi 2.0.

Kaidah dan pengambilan keputusan :

Untuk kaidah dan pengambilan keputusan dilakukan dengan membandingkan $t$ tabel dan $t$ hitung:

- Jika t hitung $\geq \mathrm{t}$ tabel, maka $\mathrm{H}_{0}$ diterima.

- Jika thitung $<\mathrm{t}$ tabel, maka $\mathrm{H}_{0}$ ditolak.

\section{HASIL PENELITIAN DAN PEMBAHASAN \\ 4.1 Hasil Penelitian}


Gambaran hasil penelitian diakhiri oleh penyajian hasil uji coba efektivitas pengembangan model pelatihan kecakapan hidup dalam upaya memelihara kembali kemampuan keaksaraan warga belajar menggambarkan :

Tabel 4.1

Tebel Nilai Pre Test dan Post Test

Peserta Pengembangan Model Pelatihan Kecakapan dan Pendampingan

Kewirausahaan terhadap Upaya Memelihara Kemampuan Keaksaraan Warga Belajar di Kecamatan Bungbulang Kabupaten Garut Provinsi Jawa Barat

\begin{tabular}{|c|c|c|}
\hline \multirow{2}{*}{ Responden } & \multicolumn{2}{|c|}{ Nilai } \\
\cline { 2 - 3 } & Pre Test & Poss Test \\
\hline 1 & 40 & 85 \\
\hline 2 & 35 & 90 \\
\hline 3 & 30 & 90 \\
\hline 4 & 45 & 95 \\
\hline 5 & 40 & 85 \\
\hline 6 & 40 & 85 \\
\hline 7 & 40 & 90 \\
\hline 8 & 25 & 80 \\
\hline 9 & 30 & 80 \\
\hline 10 & 35 & 85 \\
\hline
\end{tabular}

Sumber : Nilai hasil pre test dan post test.

Dari nilai pre test dan post test seperti yang tersebut dalam tabel terebut di atas, untuk mengetahui t-hitung, t-tabel guna pengambilan keputusan hipotesis, peneliti melalukannya dengan menggunakan alat bantu statistik Analisis Statistik MS Excel. Statistik analisis MS Excel ini kemudian dikonversi ke word menjadi sebagai berikut :

Tabel 4.2

Peserta Pengembangan Model Pelatihan Kecakapan dan Pendampingan

Kewirausahaan terhadap Upaya Memelihara Kemampuan Keaksaraan Warga Belajar di Kecamatan Bungbulang Kabupaten Garut Provinsi Jawa Barat

t-Test: Paired Two Sample for Means

\begin{tabular}{lrr}
\hline & X1 (Model lama) & X2 (Model baru) \\
\hline Mean & 36 & 86.5 \\
Variance & 37.77777778 & 22.5
\end{tabular}




\section{Observations}

Pearson Correlation

Hypothesized Mean Difference

df

t Stat (t hitung)

$\mathrm{P}(\mathrm{T}<=\mathrm{t})$ one-tail

t Critical one-tail

$\mathrm{P}(\mathrm{T}<=\mathrm{t})$ two-tail

t Critical two-tail
10

10

0.609772747

\section{0}

9

$-32.11793576$

6.75582E-11

1.833112933

$1.35116 \mathrm{E}-10$

2.262157163

$\mathrm{t}$ tabel $=\operatorname{TINV}(0.05,9)$

2.262157163

Sumber : Hasil pengolahan data dan konversi analisis statistik microsoft excel ke word.

T- tabel :

Tingkat signifikansi adalah 5\% ( $\alpha=0.05)$, sedangkan degree of freedom $(d f)$ sebesar $\mathrm{n}$ $-1=9$. Untuk program Excel nilai probabilitas harus dikali 2, sehingga untuk 0,05 dalam program menjadi $\mathrm{t}$ tabel $=\operatorname{TINV}(0.05,9)=2.262157163$ atau 2,2622. Dalam kasus ini dipakai perhitungan satu sisi karena adanya penggunaan " $<$ " pada perumusan hipotesis. Juga tanda "<" berarti pengujian dilakukan pada sisi kiri dari distribusi normal yang berarti angka $t$ tabel di atas menjadi-2,2622

T-hitung

Dari hasil output komputer di atas, pada baris keterangan "t Stat" didapat hasil t hitung sebesar - 32,1179

Kaidah dan pengambilan keputusan

Dengan membandingkan $\mathrm{t}$ tabel dan $\mathrm{t}$ hitung :

- $\quad$ Jika t hitung $\geq \mathrm{t}$ tabel, maka $\mathrm{H}_{0}$ diterima.

- $\quad$ Jika t hitung $<\mathrm{t}$ tabel, maka $\mathrm{H}_{0}$ ditolak.

Dari kaidah keputusan di atas maka:

Karena $\mathrm{t}$ hitung $(-32,1179)<\mathrm{t}$ table $(-2,2622)$, maka Ho ditolak, artinya bahwa sesungguhnya ada perbedaan nyata (signifikan) antara rata-rata sebelum dan sesudah mengunakan model baru dalam upaya memelihara kemampuan keaksaraan, yang berarti bahwa pengembangan model pelatihan kecakapan hidup dan pendampingan kewirausahaan terhadap upaya memelihara kemampuan keaksaraan warga belajar yang dilakukan telah efektif dengan kata lain bahwa pengembangan model baru sebagal treatment dalam eksperiman dalam upaya memelihara kemampuan keaksaraan lebih efektif dibanding model sebelumnya. Hal ini dapat digambarkan seperti berikut.

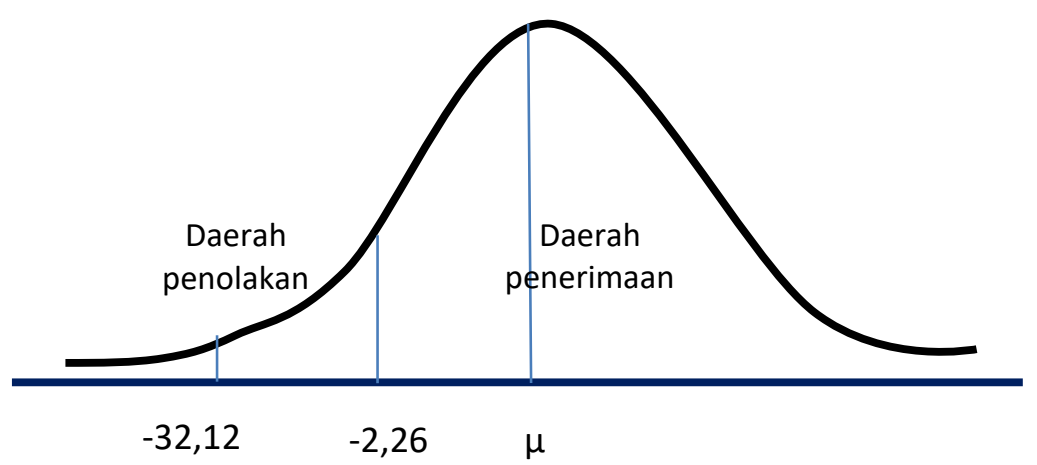


Gambar 3 : Daerah penolakan dan daerah penerimaan.

\subsection{Pembahasan Hasil Penelitian}

Kemampuan kembali keaksaraan warga belajar yang sudah mendapat perlakukan melalui eksperimen, secara signifikan lebih efektif dibanding model lama. Ini berarti bahwa pengembangan model baru terbukti secara signifikan berpengaruh dalam upaya memelihara kemampuan keaksaraan warga belajar sehingga tidk buta aksara kembali. Hal ini selaras dengan tulisan Kusnadi yang menyatakan bahwa melalui pendekatan ekonomi diharapkan dapat lebih memotivasi warga belajar dalam memelihara keaksaraan (Kusnadi, dkk.,2005: 10). Demikian juga bahwa pengembangan model baru sebagai salah satu inovasi nampaknya selaras dengan tulisan Sihombing (1999: 52) yang menyatakan, bahwa "...pendidikan masyarakat itu tidak perlu harus ada program yang standar, berbagai model harus dikembangkan". Salah satu model yang dikonstruk oleh peneliti adalah model pelatihan kecakapan hidup dan pendampingan kewirausahaan, dengan demikian nama modelnya adalah : "Model Pelatihan Kecakapan Hidup dan Pendampingan Kewirausahaan terhadap Upaya Memelihara Kemampuan Keaksaraan Warga Belajar di Kecamatan Bungbulang Kabupaten Garut Provinsi Jawa Barat".

Pengujian signifikansi efektifitas pengembangan model baru dilakukan melalui eksperimen model (before-after) yang menggunakan 10 orang warga belajar yang diambil secara random. Selanjutnya 10 orang warga belajar tersebut dilakukan tes perbuatan sebelum dan sesudah mengikuti pelatihan kecakapan hidup model baru. Untuk teknik analisis data pengembangan model pelatihan kecakapan hidup berbasis potensi lokal (before-after) terhadap satu kelompok (one group pretestposttest design) dan membuktikan signifikansi perbedaan sebelum dan sesudah dilakukan eksperimen melalui pengembangan model baru perlu diuji secara statistik dengan $t$-test berkorelasi ( related ). Tingkat signifikansi adalah 5\% $(\alpha=0.05)$, sedangkan degree of freedom $(d f)$ sebesar $\mathrm{n}-1=9$. Untuk program Excel nilai probabilitas harus dikali 2, sehingga untuk 0,05 dalam program menjadi $\mathrm{t}$ tabel $=$ $\operatorname{TINV}(0.05,9)=2.262157163$ atau 2,2622. Dalam kasus ini dipakai perhitungan satu sisi karena adanya penggunaan " $<$ " pada perumusan hipotesis. Juga tanda " $<$ " berarti pengujian dilakukan pada sisi kiri dari distribusi normal yang berarti angka $t$ tabel di atas menjadi - 2,2622. Dari hasil output komputer di atas, pada baris keterangan "t Stat" didapat hasil t hitung sebesar $-32,1179$. Karena t hitung $(-32,1179)<\mathrm{t}$ table $(-$ 2,2622), maka Ho ditolak, artinya bahwa sesungguhnya ada perbedaan nvata (signifikan) antara rata-rata sebelum dan sesudah pengembangan model $\mathrm{b}$ berarti bahwa pengembangan model baru yang dilakukan telah efektif $\mathrm{d} \epsilon$ lain bahwa pengembangan model baru sebagal treatment dalam eksperimaı upaya memelihara kemampuan keaksaraan warga belajar terbukti lebih efektif dibanding model sebelumnya.

\section{KESIMPULAN DAN SARAN \\ 5.1 Simpulan}

Terdapat beberapa kesimpulan sebagai jawaban atas permasalahan penelitian sebagai berikut : (1) Pelatihan model lama dilaksanakan dengan materi tunggal yaitu kecakapan vokasional/kejuruan tanpa ada pendampingan kewirausahaan sehingga kemampuan keaksaraan tidak perpelihara dan mereka buta aksara kembali; (2) Model konsptual dilaksanakan sebagai bentuk treatment melalui eksperimen 
kepada 10 peserta yang berlangsung selama delapan hari efektif dengan waktu dan tempat disesuaikan dengan situasi dan kondisi peserta. Implenentasi penyelenggaraan dilakukan bersama-sama antara peneliti dengan pengelenggara pendidikan terdahulu/sebelumnya melalui prosedur atau tahapan baku yaitu tahap pesiapan pelatihan, tahap pelaksanaan pelatihan, dan tahap evaluasi; (3) Efektivitas pengembangan model baru diketahui, bahwa thitung $(-32,1179)<\mathrm{t}$ tabel $(-2,2622)$, maka Ho ditolak, artinya bahwa sesungguhnya ada perbedaan nyata (signifikan) antara rata-rata sebelum dan sesudah pengembangan model baru yang berarti bahwa model baru yang dilakukan lebih efektif dengan kata lain bahwa model baru sebagal treatment lebih efektif dibanding model sebelumnya.

\subsection{Saran}

Sebagai tindak lanjut dan implikasi dari temuan penelitian ini, disarankan hal-hal sebagai berikut : (1) Saran untuk rekonstruksi pelatihan dengan model baru, ternyata telah terbukti sangat efektif. Sehubungan itu perlu diupayakan penyebarluasan model ini pada program/kegiatan sejenis pada peserta pelatihan; (2) Saran untuk Pemerintah (Pengambil Kebijakan), pihak pemerintah, cukup memberikan rambu-rambu standar kompetensi yang harus dikuasai peserta pelatihan, sementara tujuan pelatihan, materi, media, dan strategi pelatihan dikemas secara kreatif oleh fasilitator dan penyelenggara; (3) Saran untuk praktisi pelatihan, dapat menjadikan hasil penelitian ini sebagai pembanding atau rujukan penyelenggaraan pelatihan serupa dengan sifat pembelajaran/pelatihan disesuaikan dengan tujuan serta ranah yang hendak dicapai.

\section{DAFTAR PUSTAKA}

[1] Abdulhak, I. (1990). Program Kerja Paket A Hubungannya dengan motivasi Meningkatkan Pendapatan dan Motivasi Mengikuti Pendidikan Lanjutan. Disertasi Sekolah Pascasarjana IKIP Jakartaa: Tidak diterbitkan.

[2] Anwar. (2008). Pendidikan Kecakapan Hidup. Bandung: Alfabeta.

[3] Arikunto, S. (2002). Dasar-dasar Evalkuasi Pendidikan. Jakarta: Bumi Aksara.

[4] Borg dan Gall. (1996). Educational Research: An Inroduction (Third Ed). New York: Longman.

[5] Buku Modul Keaksaraan Berbasis Masyarakat Desa. 2008. Direktorat Pendidikan Masyarakat. Direktorat Jendral Pendidikan Nonformal dan Informal. Departemen Pendidikan nasional. Jakarta.

[6] Djakman, D, C dan Silvira, V. (1994). Sain Manajemen. Buku Dua. Edisi Ke Empat. Jakarta: Salemba.

[7] Geoffrey. G. M. (1996). Kewirausahaan: Teori dan Praktik. Jakarta: Pustaka Presindo.

[8] Hatimah, I. (2005). Pengembangan Model Pengelolaan Pembelajaran Berbasis Potensi Lokal. Disertasi Doktor pada Sekolah Pascasarjana UPI Bandung: Tidak diterbitkan.

[9] Hatimah, I, dkk (2007). Pembelajaran Berwawasan Kemasyarakatan (Edisi Satu). Jakarta: Universitas Terbuka.

[10] Irianto, A. (2007). Statistik: Konsep Dasar dan Aplikasinya. Jakarta: Kencana.

[11] Kamil, M. (2010). Model Pendidikan dan Pelatihan: Konsep dan Aplikasi. Bandung: CV Alfabeta.

[12] Kusmiadi, A. (2009). "Model Pembelajaran Pasca Keaksaraan Melalui Penguatan Pendidikan Kecakapan Hidup Bagi Upaya Pemberdayaan Perempuan Pedesaan”. Jurnal PNFI.1, (1),11. 
[13] Kusnadi, dkk. (2005). Pendidikan Keaksaraan: Filosofi, Strategi, Implementasi. Jakarta: Departemen Penidikan Nasional Dirjen PLS, Direktorat Dikmas.

[14] McMillan. J.H. dan Schumacher.S. (2001). Researh and Education: A Conceptual Introduction (Fifth Ed). New York: Longman.

[15] Millan, Mc. J, dan Schumacher, S. (1999). Research In Education. New York: Longman.

[16] Sihombing, U. (2001). Pendidikan Luar Sekolah: Masalah, Tantangan dan Peluang. Jakarta: CV Wirakarsa.

[17] Sihombing, U. (2000). Pendidikan Luar Sekolah: Manajemen Strategi. Jakarta: PD Mahkota.

[18] Srinivasan, L. (1977). Beberapa Pandangan Mengenai Pendidikan Nonformal Bagi Orang Dewasa (Terjemahan). Bandung: BPKB Jayagiri.

[19] Sudjana. (2004). Pendidikan Nonformal: Wawasan, Sejarah Perkembangan, Filsafat, Teori Pendukung, Asas. Cetakan Pertama. Bandung; Falah Production.

[20] Sugiyono. (2007). Metode Penelitian Administrasi. Bandung: Alfabeta.

[21] Sugiyono. (2007). Metode Penelitian Administrasi: Dilengkapi dengan Metode $R \& D$. Bandung: ALFABETA.

[22] Sugiyono. (2009). Metode Penelitian Kuantitatif, Kualitatif dan $R \& D$. Bandung: Alfabeta.

[23] Suryadi, A. (2009). Mewujudkan Masyarakat Pembelajar: Konsep, Kebijakan dan Implementasi. Bandung: Widya Aksara Press.

[24] Suryana (2003). Kewirausahaan: Pedoman Praktis, Kiat dan Proses Menuju Sukses. Jakarta: PT Salemba Empat.

[25] Wahyudin. (2000). Modul Pelatihan Untuk Pelatih. BAPPENAS : Jakarta. 